\title{
Correction to: Depths of magma chambers at three volcanic provinces in the Karlıova region of Eastern Turkey
}

\author{
Özgür Karaoğlu ${ }^{1} \cdot$ John Browning ${ }^{2,3} \cdot$ Mohamed K. Salah $^{4} \cdot$ Abdelsalam Elshaafi $^{5} \cdot$ Agust Gudmundsson $^{6}$
}

Published online: 8 September 2018

(C) Springer-Verlag GmbH Germany, part of Springer Nature 2018

\section{Correction to: Bulletin of Volcanology (2018) 80:69}

https://doi.org/10.1007/s00445-018-1245-x

In the article "Depths of magma chambers at three volcanic provinces in the Karliova region of Eastern Turkey", the figure captions for Fig. 4 and Fig. 5 were switched. The correct figures and their captions are as follows:

The online version of the original article can be found at https://doi.org/ $10.1007 / \mathrm{s} 00445-018-1245-\mathrm{x}$

Özgür Karaoğlu

ozgur.karaoglu@deu.edu.tr; cougarforever@gmail.com

1 Department of Geological Engineering, Eskișehir Osmangazi University, 26040 Eskişehir, Turkey

2 Department of Earth Sciences, University College London, Gower Street, London WC1E 6BT, UK

3 Department of Mining Engineering and Department of Structural and Geotechnical Engineering, Pontificia Universidad Católica de Chile, Santiago, Chile

4 Department of Geology, American University of Beirut, Riad El Solh, Beirut 1107 2020, Lebanon

5 Department of Earth Sciences, Faculty of Sciences, Benghazi University, Benghazi, Libya

6 Department of Earth Sciences, Royal Holloway University of London, Egham TW20 0EX, UK 


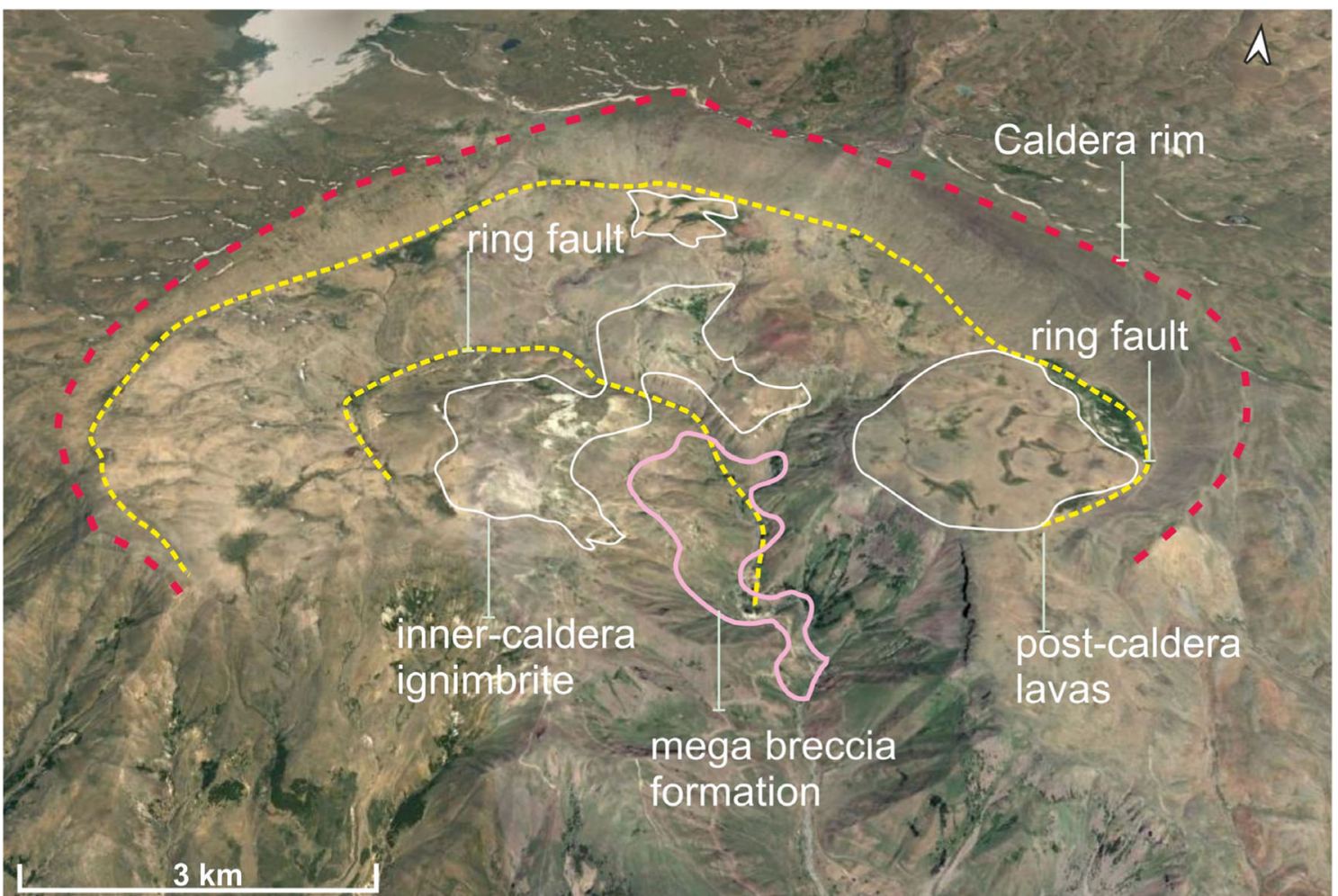

Fig. 4 The main structures of Varto caldera projected on a Google Earth, DigitalGlobe, image. The structures include the main ring fault (caldera rim) as well as two smaller but concentric ring faults, making the caldera nested

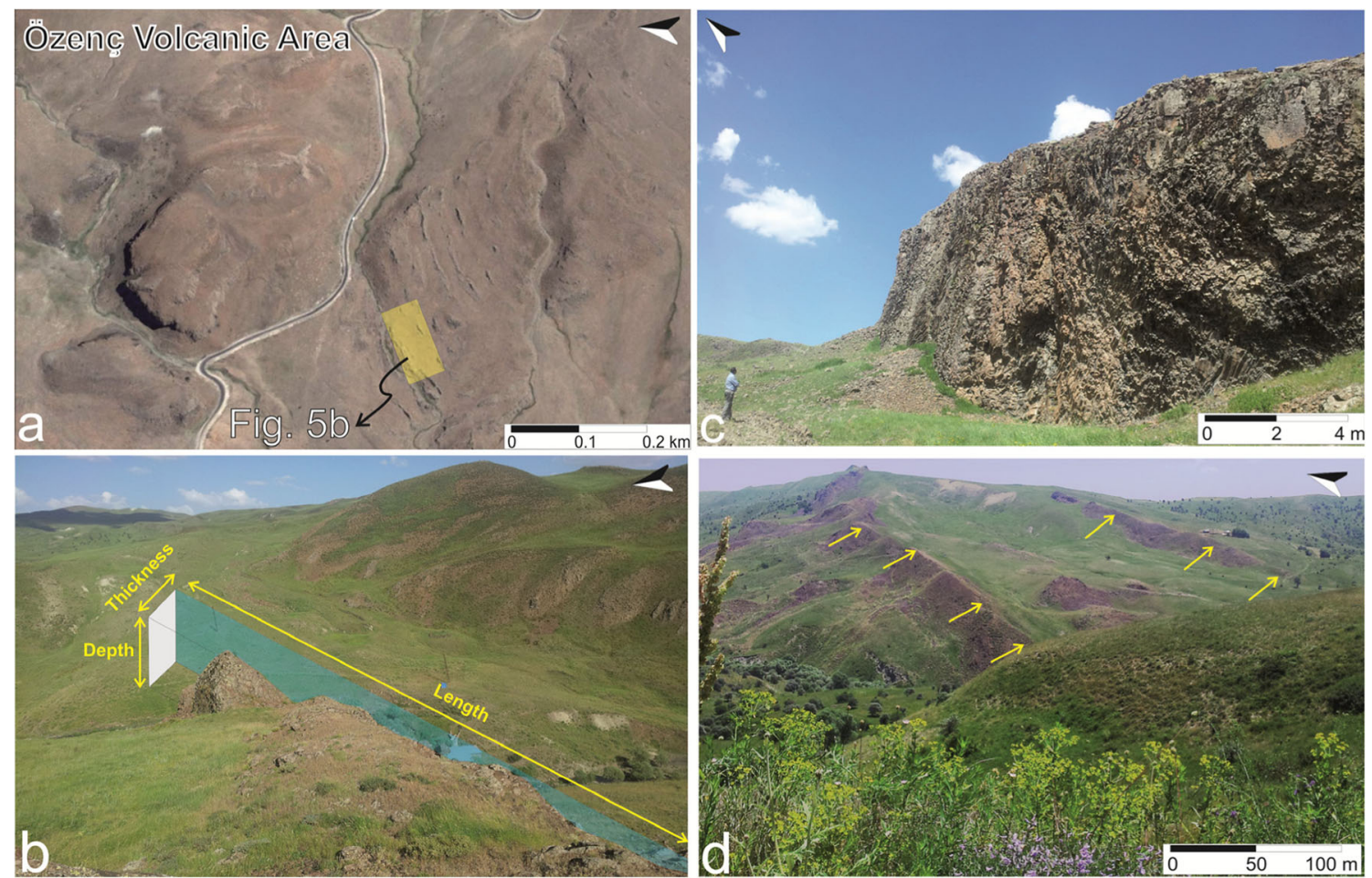

Fig. 5 a Google Earth, DigitalGlobe, image of dikes at Özenç volcanic area; $\mathbf{b}, \mathbf{c}$, and $\mathbf{d}$ are images of dikes and volcanic fissures at the Özenç volcanic area 
Furthermore, the decimal separator of the original Table 1 was incorrectly given as a comma, and has been amended as follows.

Table 1 Dike parameter values for Varto caldera, Turnadağ volcano and Özenç volcanic areas

\begin{tabular}{lllllll}
\hline Dyke & $\Delta \mathrm{u} 1(\mathrm{~m})$ & $\mathrm{p}_{\mathrm{o}}(\mathrm{MPa})$ & $\mathrm{L}(\mathrm{m})$ & $\rho_{\mathrm{m}}\left(\mathrm{kg} \mathrm{m}^{-3}\right)$ & $\mathrm{h}(\mathrm{km})$ & Strike $\left(^{\circ}\right)$ \\
\hline D1-Varto caldera & 0.85 & 13.41 & 169 & 2475 & 2.80 & 290 \\
D2-Varto caldera & 1.40 & 13.58 & 275 & 2475 & 2.85 & 300 \\
D3-Varto caldera & 1.00 & 13.75 & 194 & 2475 & 2.90 & 205 \\
D4-Varto caldera & 1.10 & 14.45 & 203 & 2475 & 3.12 & 280 \\
D5-Varto caldera & 1.00 & 12.94 & 206 & 2475 & 2.65 & 282 \\
D6-Varto caldera & 1.10 & 15.69 & 187 & 2475 & 3.51 & 291 \\
D7-Varto caldera & 1.10 & 13.46 & 218 & 2475 & 2.81 & 279 \\
D8-Varto caldera & 1.25 & 21.23 & 157 & 2475 & 5.25 & 295 \\
D9-Turnadağ volcano & 1.30 & 17.69 & 196 & 2475 & 4.14 & 70 \\
D10-Turnadağ volcano & 1.00 & 13.82 & 193 & 2475 & 2.92 & 66 \\
D11-Turnadağ volcano & 1.10 & 14.45 & 203 & 2475 & 3.12 & 81 \\
D12-Turnadağ volcano & 0.80 & 16.28 & 131 & 2475 & 3.70 & 70 \\
D13-Turnadağ volcano & 0.65 & 13.33 & 130 & 2475 & 2.77 & 68 \\
D14-Turnadağ volcano & 0.55 & 13.84 & 106 & 2475 & 2.93 & 74 \\
D15-Özenç volcanic area & 2.50 & 26.67 & 250 & 2700 & 22.60 & 85 \\
D16-Özenç volcanic area & 2.75 & 31.88 & 230 & 2700 & 27.91 & 78 \\
D17-Özenç volcanic area & 2.30 & 30.67 & 200 & 2700 & 26.67 & 89 \\
D18-Özenç volcanic area & 3.00 & 29.63 & 270 & 2700 & 25.62 & 91 \\
D19-Özenç volcanic area & 2.70 & 28.80 & 250 & 2700 & 24.77 & 93 \\
D20-Özenç volcanic area & 3.30 & 30.34 & 290 & 2700 & 26.35 & 89 \\
D21-Özenç volcanic area & 2.70 & 27.69 & 260 & 2700 & 23.64 & 93 \\
\hline
\end{tabular}

The columns are as follows: thickness of the dike $\left(\Delta u_{I}\right)$, calculated magma overpressure in the dike $\left(p_{o}\right)$, along strike length of the dike $(L)$, the average density of the magma in the dike $\left(\rho_{m}\right)$, calculated depth of origin of the dike $(h)$, and strike of the dike. Some constant values are used as follows: Poisson'ratio $(\nu)$ is 0.25 , Young's modulus of the host rock $(E)$ is $5 \mathrm{GPa}$, the average density of the host rock $\left(\rho_{r}\right)$ is $2800 \mathrm{~kg} \mathrm{~m}^{-3}$, internal excess magmatic pressure in the chamber $\left(p_{e}\right)$ is $3.5 \mathrm{MPa}$, acceleration due to gravity $(g)$ is 9.81 , and the differential stress $\left(\sigma_{d}\right)$ is $1 \mathrm{MPa}$ 